\title{
PERSEPSI PELANGGAN TERHADAP KUALITAS PELAYANAN PUBLIK PERUSAHAAN LISTRIK NEGARA (PLN) UNIT PELAYANAN DAN JARINGAN (UPJ) BEKASI KOTA
}

\author{
Dahlia Dessianyanthi ${ }^{1)}$, Aida Vitayala S. Hubeis ${ }^{2)}$ \\ 1) Mahasiswa, Departemen Sains Komunikasi Pengembangan Masyarakat, Fakultas Ekologi Manusia, \\ Institut Pertanian Bogor, I34060041 \\ ${ }^{2)}$ Dosen Pembimbing, Departemen Sains Komunikasi Pengembangan Masyarakat, Fakultas Ekologi \\ Manusia, Institut Pertanian Bogor, Prof, Dr, Ir.
}

\begin{abstract}
Public service is one form of the state apparatus functions as a public servant as well as a servant of the state. Seeing an increasingly competitive business world today, the company that provide public service need to change their customer services into a profit center. The quality of service provides an important link between the company and customers, also can help to push the company to achieve their goals and give positive image. Company's image depends on how the company give their services to the customer. Companies are required to constantly monitor public perceptions or opinions about the company, through its institutional functions of Public Relation (PR). The purpose of this research is to analyze the customer's perception of the quality of public services at PLN UPJ Bekasi Kota, and the relationship between the internal and external factors with the customer's perception of public services at PLN UPJ Bekasi Kota. The results of this research show the customer's perception on the quality of public services at PLN UPJ Bekasi Kota is good with the average score equal to 3.86. Correlation test showed that there are five significant correlation, which is the relationship between education level and assurance, education level and responsiveness, education level and tangibles, income level and tangibles, and the frequency of respondents calling and responsiveness.
\end{abstract}

Keywords: Public Service, Quality of Service, PLN

\subsection{Latar Belakang}

\section{PENDAHULUAN}

PT. Perusahaan Listrik Negara (PLN) merupakan salah satu contoh Badan Usaha Milik Negara (BUMN). Berdasarkan PP No.23 Tahun 1994, PT. PLN (Persero) merupakan BUMN pemegang kuasa usaha ketenagalistrikan, yang bertugas menyediakan tenaga listrik bagi kepentingan umum dalam jumlah dan mutu yang memadai, serta menyelenggarakan usaha-usaha lain yang menunjang usaha penyediaan tenaga listrik (Undang-Undang Republik Indonesia No. 30 Tahun 2009 Tentang Ketenagalistrikan). PLN termasuk salah satu BUMN penyedia pelayanan publik. Pelayanan publik (public service) merupakan salah satu perwujudan dari fungsi aparatur negara sebagai abdi masyarakat disamping sebagai abdi negara. Pelayanan publik oleh birokrasi publik dimaksudkan untuk mensejahterakan masyarakat (warga negara) dari satu negara kesejahteraan (welfare state) ${ }^{1}$.

Citra PLN sebagai perusahaan bergantung pada bagaimana perusahaan tersebut memberikan pelayanan kepada publik. Keberadaan publik sangat penting bagi PLN, karena kualitas pelayanan dinilai berdasarkan persepsi publik bukan berdasarkan persepsi penyedia jasa. Oleh karena itu praktisi Humas PLN dituntut untuk terus memantau persepsi atau opini masyarakat yang sedang berkembang mengenai perusahaan. Opini masyarakat tersebut nantinya akan menjadi input bagi Humas dan

\footnotetext{
${ }^{1}$ Irfan Langgo. 2009. Pelayanan Publik PLN dan Realitasnya di Lapangan. http://irfanlanggo.dagdigdug.com/2009/09/06/pelayanan-publik-pln-dan-realitasnya-di-lapangan/ diakses pada 29 Maret 2010
} 
perusahaan dalam menyusun strategi untuk melakukan perbaikan kinerja selanjutnya dan membawa perusahaan kepada citra yang positif

\subsection{Perumusan Masalah}

Tahun 2010 menjadi momentum yang sangat penting dalam sejarah PLN. Di awal tahun 2010, Direktorat Operasi Jawa Bali mencanangkan peningkatan kinerja operasi dan layanan setara kelas dunia sebagai fokus utama program kerja 2010 - 2012. Upaya tersebut selanjutnya diikuti dengan penunjukan 25 unit PLN se-Jawa untuk menjadi pilot project, termasuk PLN APJ Bekasi yang merupakan induk dari UPJ Bekasi Kota. Program-program perubahan tersebut telah berjalan dalam triwulan kedua. Untuk itu perlu untuk diketahui bagaimana sejauh ini respon yang diberikan pelanggan terhadap perubahan-perubahan yang dilakukan, sehingga dapat menjadi evaluasi selanjutnya bagi manajemen dan Humas agar dapat segera menyusun perbaikan pelayanan menjadi lebih baik.Berdasarkan pemaparan tersebut, perumusan masalah yang dikaji dalam penelitian ini adalah:

1. Bagaimana persepsi pelanggan terhadap pelayanan publik PLN UPJ Bekasi Kota?

2. Bagaimana hubungan faktor internal pelanggan dengan persepsi pelanggan terhadap pelayanan publik PLN UPJ Bekasi Kota?

3. Bagaimana hubungan faktor eksternal pelanggan dengan persepsi pelanggan terhadap pelayanan publik PLN UPJ Bekasi Kota?

\subsection{Tujuan Penelitian}

Adapun tujuan penelitian ini adalah untuk:

1. Menganalisis persepsi pelanggan terhadap pelayanan publik PLN UPJ Bekasi Kota.

2. Menganalisis hubungan faktor internal dengan persepsi pelanggan terhadap pelayanan publik PLN UPJ Bekasi Kota.

3. Menganalisis hubungan faktor eksternal dengan persepsi pelanggan terhadap pelayanan publik PLN UPJ Bekasi Kota.

\subsection{Tinjauan Pustaka}

\section{PENDEKATAN TEORITIS}

\subsubsection{Public Relations dalam Perusahaan}

Hubungan masyarakat (Humas) atau Public Relations (PR) merupakan bidang atau fungsi tertentu yang diperlukan oleh setiap organisasi, baik itu organisasi yang bersifat komersial (perusahaan) maupun organisasi nonkomersial. Humas adalah komunikasi dua arah antara organisasi dan publik secara timbal balik dalam rangka mendukung fungsi dan tujuan manajemen dengan meningkatkan pembinaan kerja sama dan pemenuhan kepentingan bersama (Effendy 1991).

Humas bertujuan membentuk goodwill, tolerance (toleransi), mutual understanding (saling kerja sama) dan mutual appreciation (saling menghargai) serta memperoleh opini publik yang favorable, dan image yang tepat berdasarkan prinsip-prinsip hubungan yang harmonis baik hubungan ke dalam atau internal relations maupun hubungan ke luar atau external relations (Ruslan 1998).

Humas memonitor, merekam, dan mengevaluasi tanggapan serta pendapat umum atau masyarakat. Disamping itu, peka terhadap perubahan yang terjadi di lingkungan kehidupan organisasi. Tren yang muncul dianalisis dan diolah sehingga bisa diatasi dengan tepat, benar, dan menguntungkan bagi semua pihak. Jika tanggapan dari publik terhadap perusahaan ternyata buruk, maka tugas seorang PR memperbaiki citra organisasi (Rumanti 2002).

\subsubsection{Strategi Public Relations}

Arti dari strategi adalah bagian terpadu dari suatu rencana, sedangkan rencana merupakan produk dari perencanaan, yang pada akhirnya perencanaan adalah salah satu fungsi dari proses 
manajemen. Sebuah strategi harus memiliki tujuan yang sudah ditentukan, maka selanjutnya dapat dirumuskan "apa dan bagaimana” strategi dilancarkan (Ruslan 1998). Strategi juga dapat diartikan sebagai pola rencana yang mengacu pada misi, tujuan, kebijakan dan metode yang diperlukan untuk mencapai tujuan-tujuan organisasi.

Terdapat lima strategi untuk membangun citra perusahaan, antara lain (Ruslan 2004):

1. Melalui citra perusahaan itu sendiri (identitas perusahaan).

2. Melalui citra produk yang diproduksi perusahaan.

3. Melalui pelayanan jasa yang diberikan kepada publik.

4. Melalui penampilam pemberian pelayanan.

5. Melalui citra perusahaan saingan.

\subsubsection{Citra Perusahaan}

Citra merupakan tujuan utama dan sekaligus merupakan reputasi dan prestasi yang hendak dicapai PR. Meskipun demikian pengertian citra itu sendiri abstrak (intangible) dan tidak dapat diukur secara matematis, tetapi wujudnya bisa dirasakan dari hasil penilaian baik dan buruk (Ruslan 1998). Penilaian atau tanggapan masyarakat tersebut dapat berkaitan dengan timbulnya rasa hormat, kesankesan yang baik dan menguntungkan terhadap suatu citra organisasi atau merek produk atau jasa yang diwakili oleh pihak public relations.

\subsubsection{Persepsi dan Opini Publik}

Persepsi pada hakekatnya adalah proses kognitif yang dialami setiap orang di dalam memahami informasi tentang lingkungan, baik melalui penglihatan, pendengaran, penghayatan, perasaan dan penciuman (Sarwono 1999). Sarwono menjelaskan bahwa persepsi seseorang dipengaruhi faktor internal dan eksternal. Faktor internal adalah faktor-faktor yang terdapat dalam diri individu, seperti jenis kelamin, perbedaan generasi (usia), tingkat pendidikan, dan tingkat pengetahuan. Faktor eksternal merupakan faktor yang berasal dari lingkungan di luar yang mempengaruhi persepsi seseorang, seperti lingkungan sosial budaya dan media komunikasi dimana seseorang memperoleh informasi tentang sesuatu.

Persepsi dipengaruhi oleh berita yang berkembang. Berita yang berkembang sampai kepada masyarakat melalui media massa. Keterkaitan PR dan media massa tidak perlu dipertanyakan lagi. Media massa memiliki keterkaitan dengan opini publik.

Kegiatan humas memiliki sasaran untuk menciptakan opini publik yang bisa diterima dan menguntungkan semua pihak (Rumanti 2002). Menurut Rumanti (2002) opini publik dapat mempengaruhi kualitas kerja Humas dalam mengkomunikasikan pesan-pesan kepada publik. Opini publik erat sekali hubungannya dengan perilaku manusia, sehingga dapat mewarnai dan memberi masukan kepada humas.

\subsubsection{Kualitas Pelayanan Publik}

Menurut Sinambela (2008) pelayanan publik diartikan sebagai setiap kegiatan yang dilakukan oleh pemerintah terhadap sejumlah manusia yang memiliki setiap kegiatan menguntungkan dalam suatu kumpulan atau kesatuan, dan menawarkan kepuasan meskipun hasilnya tidak terikat pada suatu produk secara fisik. Selain itu, pelayanan publik merupakan pemberian layanan (melayani) keperluan orang atau masyarakat yang mempunyai kepentingan pada organisasi itu sesuai dengan aturan pokok dan tata cara yang telah ditetapkan.

Tjiptono (2006) mendefinisikan bahwa kualitas merupakan suatu kondisi yang dinamis yang berhubungan dengan produk, jasa, manusia, proses dan lingkungan yang memenuhi atau melebihi harapan. Kulitas atau mutu dari dua definisi di atas mengandung pengertian bahwa barang dan jasa yang dihasilkan dapat memuaskan atau memenuhi harapan penggunanya. 
Selanjutnya, Zietham berpendapat bahwa terdapat lima indikator pelayanan publik, yaitu (Sinambela 2008):

1. Reliability (Kehandalan), yaitu kemampuan untuk memberikan pelayanan yang sesuai dengan janji yang ditawarkan.

2. Tangibles (Wujud Fisik), meliputi penampilan fisik, seperti gedung dan ruangan front office, tersedianya tempat parkir, kebersihan, kerapihan dan kenyamanan ruangan, kelengkapan peralatan komunikasi dan penampilan karyawan.

3. Responsiveness (Ketanggapan), yaitu respon atau kesigapan karyawan dalam membantu pelanggan dan memberikan pelayanan yang cepat dan tanggap, yang meliputi kesigapan karyawan dalam menangani transaksi, dan penanganan keluhan.

4. Assurance (Jaminan), meliputi kemampuan karyawan atas pengetahuaan terhadap produk secara tepat, kualitas keramahtamahan, perhatian dan kesopanan dalam memberikan pelayanan, keterampilan dalam memberikan informasi, kemampuan dalam memberikan keamanan di dalam memanfaatkan jasa yang ditawarkan, dan kemampuan dalam menanamkan kepercayaan pelanggan dalam perusahaan.

5. Empathy (Empati), yaitu perhatian secara individual yang diberikan perusahaan kepada pelanggan, seperti kemudahan untuk menghubungi perusahaan, kemampuan karyawan untuk berkomunikasi dengan pelanggan, dan usaha perusahaan untuk memahami keinginan dan kebutuhan pelanggannya.

\subsection{Kerangka Pemikiran}

Strategi atau program terkait pelayanan prima menuju world class services (WCS) yang telah dicanangkan dan telah berjalan memerlukan penilaian dari sasarannya, yakni para pelanggan. Untuk itu perlu dikaji persepi pelanggan mengenai kualitas pelayanan PLN UPJ Bekasi Kota yang hadir dengan wajah baru di awal tahun 2010.

Kualitas pelayanan yang baik bukanlah berdasarkan persepsi penyedia jasa, melainkan berdasarkan persepsi pelanggan. Untuk mengetahui kualitas pelayanan ialah dengan menggunakan skala pengukuran berdasarkan lima dimensi service quality yaitu, reliability (keandalan), assurance (jaminan), empathy (empati), responsiveness (ketanggapan), dan tangible (bukti fisik). Setelah melakukan evaluasi terhadap kualitas pelayanan perusahaan maka hasilnya dapat menjadi gambaran bagaimana citra pelayanan PLN UPJ Bekasi Kota di mata pelanggan saat ini. 


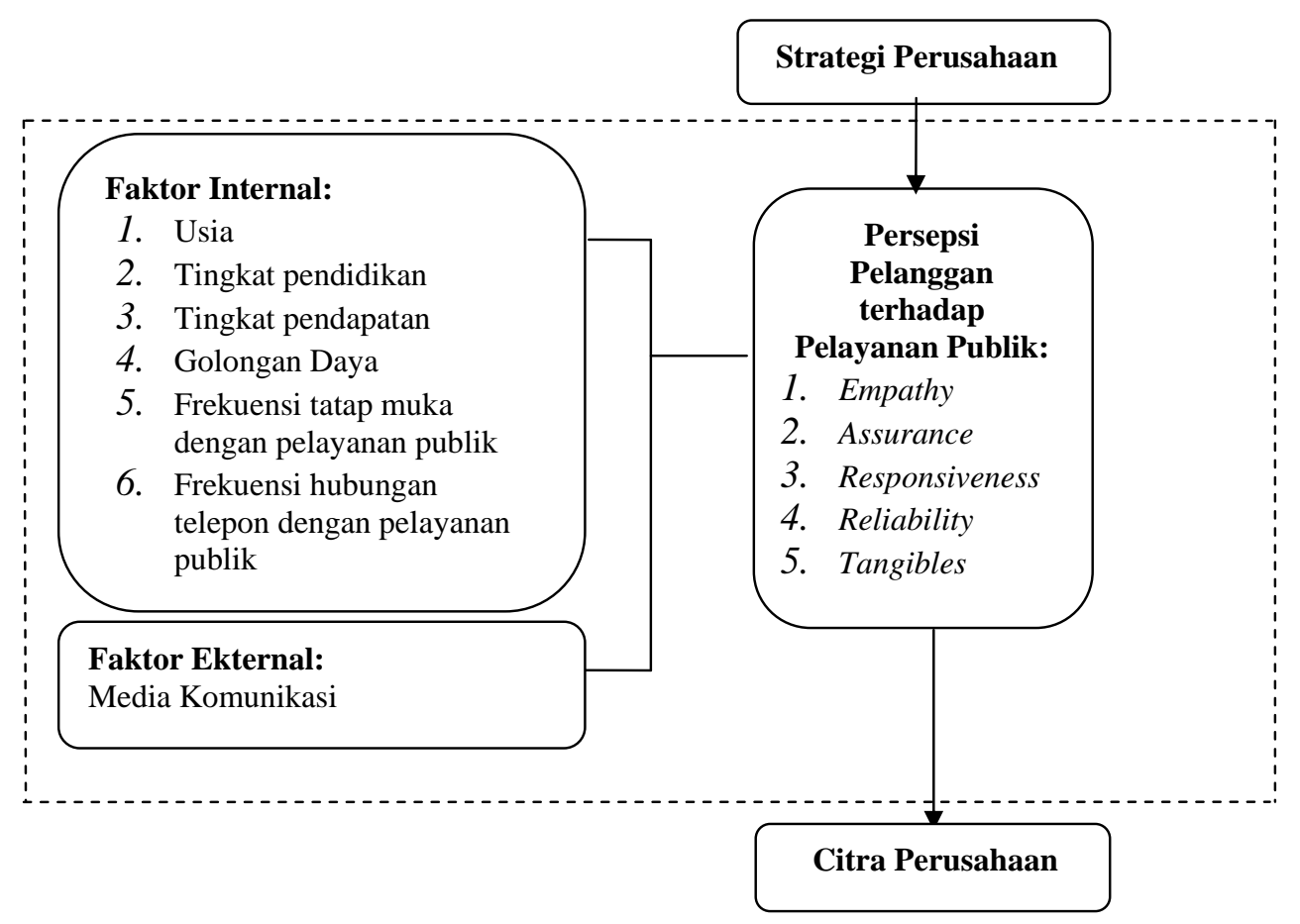

Gambar 1 Kerangka pemikiran

\subsection{Hipotesis Penelitian}

1. Diduga terdapat hubungan antara faktor internal pelanggan dengan persepsi pelanggan terhadap kualitas pelayanan publik.

2. Diduga terdapat hubungan antara faktor eksternal pelanggan dengan persepsi pelanggan terhadap kualitas pelayanan publik.

\subsection{Metode Penelitian}

\section{PENDEKATAN LAPANG}

Penelitian ini menggunakan pendekatan kuantitatif, yang menggunakan metode penelitian survai dengan didukung oleh data kualitatif. Metode penelitian survai mencakup model penelitian deskriptif. Penelitian deskriptif adalah model penelitian untuk melihat gambaran atau potret situasi atau kondisi tertentu masa kini. Penelitian deskriptif meliputi penelitian yang memperkirakan proporsi yang memiliki sikap, pendapat, pandangan, persepsi atau tingkah laku tertentu (Ruslan 2004).

\subsection{Teknik Penentuan Responden}

Sampel dalam penelitian ini ialah pelanggan Unit Pelayanan dan Jaringan (UPJ) Bekasi Kota. Responden ditentukan dengan cara accidental sampling, yaitu teknik penentuan sampel berdasarkan objek penelitian yang kebetulan dijumpai di lokasi penelitian (Ruslan 2004). Teknik accidental sampling dipilih karena alasan kemudahan dan efisiensi waktu serta biaya.

Jumlah pelanggan PT. PLN APJ Bekasi pada triwulan pertama 2010 adalah 773.505 pelanggan dan persen tingkat perkiraan kesalahan yang diinginkan adalah 10 persen. Dengan demikian, jumlah responden yang diperoleh menggunakan rumus Slovin adalah sebanyak 100 orang.

\subsection{Teknik Pengumpulan Data}

Data yang dikumpulkan adalah data primer dan data sekunder. Data primer diperoleh melalui pengamatan di lapangan dan wawancara menggunakan kuesioner yang disebarkan dan diisi oleh 
responden. Data sekunder diperoleh melalui dokumentasi dan studi literatur yang berkaitan dengan tujuan penelitian seperti buku, artikel, skripsi, tesis dan karya ilmiah lainya.

\subsection{Pengolahan dan Analisis Data}

Data kuantitatif yang diperoleh pada penelititan ini ditabulasikan, kemudian dilakukan analisis secara statistik dengan menggunakan uji statistik Chi Square dan Rank Spearman, untuk mengetahui hubungan faktor internal dan faktor eksternal dengan persepsi pelanggan terhadap pelayanan publik. Data ini diolah dengan menggunakan software SPSS 17.0 for Windows. Sedangkan data kualitatif dianalisis berdasarkan literatur dan pengetahuan yang didapat dan diintegrasikan dengan hasil dari data kuantitatif yang diperoleh lalu ditarik suatu kesimpulan.

\subsection{Waktu dan Tempat Penelitian}

Penelitian ini dilaksanakan di PT. PLN (Persero) Unit Pelayanan dan Jaringan (UPJ) Bekasi Kota di Jl. Cut Mutia No. 44 Bekasi. PLN UPJ Bekasi Kota merupakan salah satu unit yang dibawahi oleh PLN Area Pelayanan dan Jaringan (APJ) Bekasi. Pemilihan lokasi ini dilakukan secara sengaja (purposive), dengan pertimbangan PLN APJ Bekasi merupakan perusahaan pelayanan publik yang menjadi pilot project program PLN World Class Services (WCS). Waktu pengambilan data di lapangan yaitu bulan Juli 2010.

\section{GAMBARAN UMUM PERUSAHAAN}

\subsection{Profil PLN APJ Bekasi}

PT. PLN (Persero) Area Pelayanan dan Jaringan Bekasi (selanjutnya disingkat menjadi PLN APJ Bekasi) merupakan salahsatu dari 17 unit pelaksana di bawah PT. PLN (Persero) Distribusi Jawa Barat dan Banten. PLN APJ Bekasi berkedudukan di Jalan Cut Meutia nomor 44, Bekasi Timur, dengan wilayah kerja meliputi sebagian besar Kota Bekasi dan Kabupaten Bekasi, dengan total luas wilayah $1.235 \mathrm{~km}^{2}$. Dalam menjalankan proses bisnisnya, PLN APJ Bekasi membawahi sepuluh Unit Pelayanan dan Jaringan (UPJ) dan 12 Kantor Pelayanan (KP).

PLN APJ Bekasi membawahi sembilan UPJ yang melayani pelanggan tegangan rendah, yakni Bantar Gebang, Bekasi Kota, Cikarang, Tambun, Medan Satria, Lemah Abang, Mustika Jaya, Cibitung, dan Babelan serta satu UPJ tegangan menengah (UPJ Prima) yaitu Prima Bekasi. UPJ adalah unit ujung tombak PLN di level distribusi. Setiap permasalahan dan kebutuhan pelanggan (yang sifatnya rutin) menjadi tanggung jawab UPJ, baik di bidang niaga (misalnya pasang baru, perubahan daya, baca meter), operasi distribusi (penormalan gangguan, pemeliharaan jaringan), maupun penertiban pemakaian tenaga listrik (P2TL). Setiap UPJ dipimpin oleh seorang Manajer UPJ, yang dibantu oleh sejumlah staf ahli (jika ada), supervisor, staf pelaksana dan tenaga outsourcing.

Kantor Pelayanan (KP) merupakan kepanjangan tangan UPJ di wilayah-wilayah yang relatif sulit dijangkau. Kantor pelayanan biasanya diadakan untuk mendukung UPJ-UPJ dengan wilayah kerja yang luas, sehingga layanan kepada pelanggan dapat lebih maksimal. Setiap KP dipimpin oleh seorang supervisor KP yang bertanggung jawab langsung kepada Manajer UPJ, dibantu oleh sejumlah staf pelaksana dan tenaga outsourcing.

Jumlah pelanggan PLN APJ Bekasi hingga Triwulan pertama tahun 2010 mencapai 773.505 pelanggan, dengan pertumbuhan rata-rata per tahun mencapai 5,5\%. Sampai dengan Triwulan pertama tahun 2010, tenaga kerja di PLN APJ Bekasi berjumlah 1.118 orang, terdiri dari 266 pegawai PLN dan 852 tenaga outsourcing.

Visi PLN DJBB (yang sekaligus merupakan visi PLN APJ Bekasi) adalah diakui sebagai unit distribusi dengan pelayanan kelas dunia yang berlandaskan pada nilai integritas, kualitas, dan layanan modern. 


\section{Strategi Menuju PLN APJ Bekasi - World Class Services (WCS)}

Untuk mewujudkan visi layanan kelas dunia di tahun 2012, manajemen PLN APJ Bekasi merencanakan dua tahapan strategi. Strategi pertama adalah upaya membangun PLN APJ Bekasi baru. Tahapan ini dimulai pada tahun 2010 dan diharapkan mencapai hasilnya pada tahun 2011. Sedangkan tahapan kedua adalah membangun unit distribusi dengan layanan setara kelas dunia, atau yang disebut PLN APJ Bekasi - WCS. Upaya intensif pencapaian target kinerja tersebut dilakukan melalui program-program strategis arahan PLN DJBB,yang sering diistilahkan dengan Program Strategis 712-7-9, yang terdiri atas:

1. 7 program strategis membangun budaya kerja profesional;

2. 12 program strategis membangun bisnis proses excellence;

3. 7 program strategis membangun customer service excellence;

4. 9 program strategis memacu kinerja excellence.

\subsubsection{Humas PLN APJ Bekasi}

Humas pada PLN APJ Bekasi berada di bawah intruksi langsung dari Manajer APJ, namun tidak tertulis secara resmi dalam struktur organisasi. Hal ini karena tugas Humas selama ini dikerjakan bukan oleh personil khusus humas, namun dikerjakan secara bersama-sama oleh bagian pemasaran dan SDM. Pada Humas terdapat dua orang pegawai dan seorang tenaga outsourcing.

Peran dan tugas yang dilakukan pada APJ Bekasi tidak jauh berbeda dengan fungsi Humas pada umumnya, namun tetap berorientasi pada upaya meningkatkan citra perusahaan, baik produk dan pelayanannya, yakni:

1. Menerima keluhan konsumen, mengklasifikasikan keluhan melalui telepon, surat kabar, atau website, serta menjawab keluhan konsumen yang datang melalui web PLN DJBB.

2. Media monitoring, menganalisis berita lalu pengarsipan. Kegiatan ini bertujuan untuk memantau berita yang berkembang seputar PLN atau PLN APJ Bekasi. Ada sebanyak sepuluh media yang dipantau pemberitaannya.

3. Press release atau siaran pers, dimaksudkan agar pihak media mendapatkan informasi yang jelas dan tepat dari narasumber yang dapat dipercaya.

Humas PLN Bekasi juga melakukan survai kepuasan pelanggan melalui telepon, mekamisme survai ini ialah pelanggan yang mengalami gangguan di data dan setelah gangguan diperbaiki lalu selanjutnya pihak humas PLN menghubungi pelanggan untuk mendapatkan feedback terhadap layanan, apakah pelanggan merasa puas atau tidak dan juga menerima masukan dari pelanggan untuk perbaikan PLN selanjutnya.

\subsection{Perusahaan Listrik Negara (PLN) Unit Pelayanan dan Jaringan (UPJ) Bekasi Kota}

UPJ adalah unit ujung tombak PLN di level distribusi. Setiap permasalahan dan kebutuhan pelanggan (yang sifatnya rutin) menjadi tanggungjawab UPJ, baik di bidang niaga (misalnya pasang baru, perubahan daya, baca meter), operasi distribusi (penormalan gangguan, pemeliharaan jaringan), maupun penertiban pemakaian tenaga listrik (P2TL). Dengan demikian, UPJ merupakan representasi PLN APJ Bekasi di masyarakat.

UPJ Bekasi Kota, yang pelanggannya menjadi responden penelitian ini, dipimpin oleh seorang Manajer Unit dan dibantu oleh delapan orang supervisor, yang mengawasi bidang-bidang tertentu, yakni supervisor sambungan pelanggan, pelayanan pelanggan, pembacaan meter dan pengelolaan rekening, pengendalian tagihan, pengendalian keuangan dan administrasi, distribusi tegangan rendah, penertiban, dan kantor pelayanan.

Salahsatu bidang yang berhubungan dengan pelanggan ialah bidang pelayanan pelanggan. Bidang pelayanan pelanggan meliputi pelayanan produk seperti ubah daya listrik, pasang baru, pasang kembali, balik nama, penyambungan atau penambahan daya sementara dan koreksi rekening. 


\subsection{Jenis Kelamin}

\section{GAMBARAN UMUM RESPONDEN}

Hasil penelitian menunjukkan responden pelanggan yang berjenis kelamin laki-laki sebanyak 59 persen dan perempuan sebanyak 41 persen. Menurut TG (26 Tahun) salah satu petugas keamanan yang berjaga di sekitar loket, bahwa kebanyakan pelanggan yang datang langsung ke kantor pelayanan adalah laki-laki.

\subsection{Usia}

Responden dibedakan atas tiga kategori orang dewasa menurut Havighurst dan Acherman dkk dalam Mugnisyah 2008 yaitu usia dewasa awal (18-30 tahun), dewasa pertengahan (31-50 tahun), serta dewasa tua (>50 tahun). Tabel 1 menunjukkan bahwa responden pada rentang usia 18-30 tahun (dewasa muda) adalah sebanyak 14 orang, pada rentang 31-50 tahun (dewasa pertengahan) berjumlah 58 orang, serta pada rentang 50 tahun ke atas (dewasa tua) berjumlah 28 orang. Dengan demikian, dapat disimpulkan bahwa responden yang terbesar dalam penelitian adalah berasal dari kategori dewasa pertengahan yakni pada rentang umur 31-50 tahun.

Tabel 1 Jumlah dan persentase responden berdasarkan usia

\begin{tabular}{|l|c|c|}
\hline \multicolumn{1}{|c|}{ Usia } & Jumlah (orang) & Persentase (\%) \\
\hline Dewasa awal & 14 & 14 \\
\hline Dewasa pertengahan & 58 & 58 \\
\hline Dewasa tua & 28 & 28 \\
\hline Total & 100 & 100 \\
\hline
\end{tabular}

\subsection{Tingkat Pendidikan}

Tingkat pendidikan dibagi menjadi tiga kategori, yakni rendah (jika tamat dan tidak tamat SD dan sederajat), sedang (jika sedang menempuh pendidikan/ tamat SMP dan SMA sederajat), dan tinggi (jika sedang menempuh/tamat pendidikan di perguruan tinggi). Sebagian besar responden memiliki tingkat pendidikan sedang yaitu 51 persen, dengan mayoritas tingkat pendidikan SMA. Setelah itu menempati urutan kedua sebanyak 44 persen pada kategori tingkat pendidikan tinggi.

Tabel 2 Jumlah dan persentase responden berdasarkan tingkat pendidikan

\begin{tabular}{|l|c|c|}
\hline \multicolumn{1}{|c|}{ Tingkat Pendidikan } & Jumlah (orang) & Persentase (\%) \\
\hline SD & 5 & 5 \\
\hline SMP & 3 & 3 \\
\hline SMA & 48 & 48 \\
\hline Perguruan Tinggi & 44 & 44 \\
\hline Total & 100 & 100 \\
\hline
\end{tabular}

\subsection{Tingkat Pendapatan}

Tingkat pendapatan dibagi menjadi tiga kategori, yakni kategori rendah (jika pendapatan responden kurang dari Rp. 1.200.000), sedang (jika pendapatan responden antara Rp. 1.200.000 - Rp. 3.000.000), dan tinggi (jika pendapatan responden lebih dari Rp. 3.000.000). Sebanyak sepuluh persen responden memiliki pendapatan pada kategori rendah, 70 persen pada kategori sedang dan 20 persen pada kategori tinggi. Dengan demikian sebagian besar atau 70 persen responden berada pada kategori pendapatan sedang, dengan mayoritas pada tingkat pendapatan antara Rp. 2.000.001 sampai Rp. 3.000.000 sebanyak 41 orang.

Tabel 3 Jumlah dan persentase responden berdasarkan tingkat pendapatan

\begin{tabular}{|l|c|c|}
\hline \multicolumn{1}{|c|}{ Tingkat Pendapatan } & Jumlah (orang) & Persentase (\%) \\
\hline$<$ Rp. 1.200 .000 & 10 & 10 \\
\hline Rp.1.200.000 - Rp. 2.000 .000 & 29 & 29 \\
\hline Rp. 2.000.001 - Rp. 3.000.000 & 41 & 41 \\
\hline > Rp. 3.000.000 & 20 & 20 \\
\hline Total & 100 & 100 \\
\hline
\end{tabular}




\subsection{Golongan Daya Listrik}

Golongan daya listrik responden dibedakan menjadi golongan daya listrik rendah (450 watt), sedang (900-1300 watt) dan tinggi (lebih dari 1300 watt). Berdasarkan hasil pengolahan data diketahui bahwa responden sebagian besar memiliki golongan daya listrik tingkat sedang (900-1300 watt) yaitu sebesar 62 persen dari total responden. Hal tersebut mewakili gambaran pelanggan PLN UPJ Bekasi Kota yang sebenarnya, dimana sebagian besar pelanggan merupakan pengguna listrik 900-1300 watt. Tabel 4 Jumlah dan persentase responden berdasarkan golongan daya listrik

\begin{tabular}{|l|c|c|}
\hline Golongan Daya Listrik & Jumlah (orang) & Persentase (\%) \\
\hline 450 watt & 8 & 8 \\
\hline 900 watt & 13 & 13 \\
\hline 1300 watt & 49 & 49 \\
\hline$>1300$ watt & 30 & 30 \\
\hline Total & 100 & 100 \\
\hline
\end{tabular}

\subsection{Frekuensi Berhubungan dengan Pelayanan Publik}

\subsubsection{Frekuensi Berhubungan melalui Tatap Muka}

Frekuensi dihitung berdasarkan jumlah interaksi tatap muka responden dengan petugas PLN, baik petugas pada loket pelayanan maupun petugas yang datang ke rumah pelanggan, dalam enam bulan terakhir. Frekuensi berhubungan dengan petugas PLN tergolong tinggi jika responden telah lebih dari sepuluh kali melakukan interaksi tatap muka dengan petugas, tergolong sedang jika jumlah tatap muka lima sampai sepuluh kali, dan tergolong rendah jika kurang dari lima kali.

Hasil penelitian menunjukkan bahwa sebagian besar responden tergolong memiliki frekuensi interaksi tatap muka yang rendah dengan petugas PLN, yakni sebesar 69 persen.

Tabel 6 Jumlah dan persentase responden berdasarkan frekuensi tatap muka dengan petugas PLN dalam enam bulan terakhir

\begin{tabular}{|l|c|c|}
\hline \multicolumn{1}{|c|}{ Frekuensi Tatap Muka } & Jumlah (orang) & Persentase (\%) \\
\hline$<5$ kali & 69 & 69 \\
\hline $5-7$ kali & 15 & 15 \\
\hline $8-10$ kali & 2 & 2 \\
\hline$>10$ kali & 14 & 14 \\
\hline Total & 100 & 100 \\
\hline
\end{tabular}

\subsubsection{Frekuensi Berhubungan melalui Telepon}

Frekuensi dihitung berdasarkan jumlah interaksi responden melalui telepon dengan petugas PLN, baik telepon ke saluran call center 022-123 maupun telepon langsung ke kantor layanan ke nomor 021-8812222, dalam enam bulan terakhir. Frekuensi responden berhubungan dengan pelayanan publik dari PLN melalui telepon dikategorikan menjadi tiga, yakni kategori rendah (frekuensi $<5$ kali ), sedang (frekuensi 5-10 kali), dan tinggi (frekuensi > 10 kali).

Berdasarkan hasil pengolahan data pada Tabel 17 diketahui bahwa sebanyak 75 persen responden berada pada kategori rendah. Atau dengan kata lain, sebagian besar responden memiliki frekuensi interaksi melalui telepon kurang dari lima kali.

Tabel 7 Jumlah dan persentase responden berdasarkan frekuensi interaksi melalui telepon dengan petugas PLN dalam enam bulan terakhir

\begin{tabular}{|l|c|c|}
\hline \multicolumn{1}{|c|}{ Frekuensi Telepon } & Jumlah (orang) & Persentase (\%) \\
\hline$<5$ kali & 75 & 75 \\
\hline $5-7$ kali & 14 & 14 \\
\hline $8-10$ kali & 1 & 1 \\
\hline$>10$ kali & 10 & 10 \\
\hline Total & 100 & 100 \\
\hline
\end{tabular}

\subsection{Media Komunikasi}

Media komunikasi dikategorikan menjadi tiga tingkatan, yakni rendah apabila responden hanya menggunakan satu media untuk mengetahui informasi tentang pelayanan PLN, dikategorikan 
menjadi sedang jika responden menggunakan dua atau tiga media, dan dikategorikan tinggi jika responden menggunakan empat media. Pilihan media tersebut antara lain, media massa (cetak maupun elektronik), brosur atau poster, petugas PLN (melalui telepon atau datang langsung) dan yang terakhir melalui kerabat (teman atau saudara).

Tabel 8 menunjukkan bahwa sebesar 48 persen responden berada pada tingkat penggunaan media yang rendah atau hanya menggunakan satu media. Selain itu, dapat pula dilihat pada Tabel 8 bahwa media komunikasi yang paling banyak dipilih oleh responden untuk mengetahui informasi mengenai PLN ialah petugas PLN, baik melalui loket customer service ataupun telepon.

Tabel 8 Jumlah dan persentase responden berdasarkan jumlah media komunikasi

\begin{tabular}{|c|c|c|c|}
\hline Jumlah Media Komunikasi & & orang) & Persentase (\%) \\
\hline 1 media & & \multirow{4}{*}{48} & \multirow{4}{*}{48} \\
\hline Media cetak/elektronik & 17 & & \\
\hline Petugas PLN & 21 & & \\
\hline Teman/saudara & 10 & & \\
\hline \multicolumn{2}{|l|}{2 media } & \multirow{5}{*}{27} & \multirow{5}{*}{27} \\
\hline Media cetak/elektronik dan brosur/poster & 3 & & \\
\hline Media cetak/elektronik dan petugas PLN & 9 & & \\
\hline Media cetak/elektronik dan teman/saudara & 4 & & \\
\hline Petugas PLN dan teman/saudara & 11 & & \\
\hline \multicolumn{2}{|l|}{3 media } & \multirow{5}{*}{17} & \multirow{5}{*}{17} \\
\hline Media cetak/elektronik, brosur/pamflet, dan petugas PLN & 4 & & \\
\hline Media cetak/elektronik, brosur/pamflet, dan teman/saudara & 2 & & \\
\hline Media cetak/elektronik, petugas PLN, dan teman/saudara & 8 & & \\
\hline Brosur/pamflet, petugas PLN, dan teman/saudara & 3 & & \\
\hline 4 media & 8 & 8 & 8 \\
\hline Total & 100 & 100 & 100 \\
\hline
\end{tabular}

\section{PERSEPSI PELANGGAN TERHADAP PELAYANAN PUBLIK PT. PLN UPJ BEKASI KOTA}

Persepsi pelanggan PLN UPJ Bekasi Kota terhadap pelayanan publik yaitu pandangan pelanggan yang telah menjadi konsumen listrik di wilayah Bekasi terhadap kualitas pelayanan publik yang diberikan PLN, diukur melalui lima indikator service quality yaitu, reliability (kehandalan), assurance (jaminan), empathy (empati), responsiveness (ketanggapan), dan tangible (wujud fisik).

Penilaian skor dilakukan dengan menggunakan skala nilai, dengan range nilai antara satu sampai lima. Setelah diperoleh rata-rata, nilainya dikategorikan sebagai berikut, yakni sangat tidak baik jika rata-rata memiliki nilai satu (1), tidak baik jika rata-rata memiliki nilai dua (2), cukup baik jika rata-rata memiliki nilai tiga (3), baik jika rata-rata memiliki nilai empat (4), dan sangat baik jika rata-rata memiliki nilai lima (5).

Tabel 9 Rataan skor persepsi secara keseluruhan terhadap kualitas pelayanan publik PLN UPJ Bekasi Kota

\begin{tabular}{|l|c|}
\hline \multicolumn{1}{|c|}{ Indikator } & Rataan skor persepsi \\
\hline Kehandalan (Reliability) & 3,63 \\
\hline Jaminan (Assurance) & 4,01 \\
\hline Empati (Empathy) & 3,72 \\
\hline Ketanggapan (Responsiveness) & 3,89 \\
\hline Wujud Fisik (Tangibles) & 4,06 \\
\hline Total rataan skor & 3,86 \\
\hline
\end{tabular}

Keterangan: $1=$ sangat tidak baik, $2=$ tidak baik, $3=$ cukup baik, $4=$ baik, $5=$ sangat baik

Hasil rataan skor tiap inidikator pada Tabel 9 menunjukkan angka rata-rata sebesar 3,86 yang berarti persepsi pelanggan terhadap kualitas pelayanan publik PLN UPJ Bekasi Kota termasuk kategori baik. Persepsi baik terhadap kualitas pelayanan publik PLN UPJ Bekasi Kota dikarenakan pelayanan PLN UPJ Bekasi Kota sudah mengalami banyak perubahan, baik disegi pelayanan teknik 
maupun pelayanan non teknik. Sejak tahun 2010 kebijakan PLN Bekasi dibuat untuk menunjang target menjadi PLN dengan World Class Services (WCS) pada tahun 2012, salahsatunya di bidang pelayanan pelanggan yang berlandaskan pada customer service excellence. Hingga penelitian ini dilakukan, program menuju PLN - WCS telah berjalan sampai triwulan kedua (6 bulan) dimana hampir seluruh action plan dari program-program strategis telah diimplementasikan. Hasil penelitian yang menunjukkan persepsi pelanggan termasuk ke dalam kategori persepsi baik mengindikasikan bahwa sejauh ini program-program tersebut telah berjalan baik.

\subsection{Persepsi tentang Kehandalan (Reliability)}

Reliability merupakan kemampuan untuk memberikan pelayanan yang sesuai dengan janji yang ditawarkan. Aspek yang digunakan untuk melihat kehandalan pelayanan PLN UPJ Bekasi Kota antara lain mengenai ketelitian dan keakuratan dalam melayani pelanggan, pemberian pelayanan yang bebas pungutan liar, pemberian layanan tepat dengan waktu yang dijanjikan, dan kesesuaian antara prosedur yang ditetapkan dengan pelayanan di lapangan. Pada Tabel 9 (halaman 12) dapat dilihat hasil rataan skor pada indikator kehandalan mendapatkan nilai sebesar 3,63 yang berarti persepsi pelanggan terhadap kualitas pelayanan publik PLN UPJ Bekasi Kota termasuk kategori baik. Tabel 10 berikut turut menunjukkan bahwa rata-rata reponden memiliki persepsi yang baik terhadap kehandalan pelayanan publik PLN UPJ Bekasi Kota.

Tabel 10 Persepsi pelanggan terhadap kualitas pelayanan publik PLN UPJ Bekasi Kota berdasarkan pernyataan pada indikator kehandalan

\begin{tabular}{|c|c|c|c|c|c|c|c|}
\hline \multirow[t]{2}{*}{ Pernyataan } & \multicolumn{5}{|c|}{ Kehandalan } & \multirow[t]{2}{*}{ Total } & \multirow{2}{*}{$\begin{array}{l}\text { Rataan } \\
\text { skor }\end{array}$} \\
\hline & 1 & 2 & 3 & 4 & 5 & & \\
\hline Ketelitian dan keakuratan & $\begin{array}{c}1 \\
(1 \%)\end{array}$ & $\begin{array}{c}14 \\
(14 \%)\end{array}$ & $\begin{array}{c}18 \\
(18 \%)\end{array}$ & $\begin{array}{c}60 \\
(60 \%) \\
\end{array}$ & $\begin{array}{c}7 \\
(7 \%) \\
\end{array}$ & $\begin{array}{c}100 \\
(100 \%)\end{array}$ & 3,58 \\
\hline Pelayanan bebas pungli & $\begin{array}{c}3 \\
(3 \%)\end{array}$ & $\begin{array}{c}4 \\
(4 \%)\end{array}$ & $\begin{array}{c}26 \\
(26 \%)\end{array}$ & $\begin{array}{c}53 \\
(53 \%)\end{array}$ & $\begin{array}{c}14 \\
(14 \%)\end{array}$ & $\begin{array}{c}100 \\
(100 \%)\end{array}$ & 3,71 \\
\hline Pelayanan tepat waktu & $\begin{array}{c}6 \\
(6 \%) \\
\end{array}$ & $\begin{array}{c}19 \\
(19 \%) \\
\end{array}$ & $\begin{array}{c}26 \\
(26 \%) \\
\end{array}$ & $\begin{array}{c}36 \\
(36 \%) \\
\end{array}$ & $\begin{array}{c}13 \\
(13 \%) \\
\end{array}$ & $\begin{array}{c}100 \\
(100 \%)\end{array}$ & 3,31 \\
\hline $\begin{array}{l}\text { Pelayanan sesuai } \\
\text { prosedur yang berlaku }\end{array}$ & $\begin{array}{c}3 \\
(3 \%)\end{array}$ & $\begin{array}{c}5 \\
(5 \%) \\
\end{array}$ & $\begin{array}{c}14 \\
(14 \%)\end{array}$ & $\begin{array}{c}54 \\
(54 \%)\end{array}$ & $\begin{array}{c}24 \\
(24 \%)\end{array}$ & $\begin{array}{c}100 \\
(100 \%)\end{array}$ & 3,91 \\
\hline
\end{tabular}

Keterangan: $1=$ sangat tidak baik, $2=$ tidak baik, $3=$ cukup baik, $4=$ baik, $5=$ sangat baik

Tabel 10 menunjukkan bahwa responden cenderung memilih nilai empat pada setiap pernyataan. Namun masih ada keluhan dibeberapa aspek, seperti aspek ketelitian dan keakuratan petugas PLN UPJ Bekasi Kota mengenai kesalahan baca meter listrik, dan juga pada aspek ketepatan waktu pelayanan yang seringkali molor dari waktu yang dijanjikan.

\subsection{Persepsi tentang Jaminan (Assurance)}

Assurance atau jaminan yang dimaksud meliputi keterampilan karyawan yang memadai di bidangnya, kemampuan karyawan atas pengetahuaan terhadap produk secara tepat, kualitas keramahtamahan dan kesopanan dalam memberikan pelayanan, dan kemampuan dalam menanamkan kepercayaan pelanggan dalam perusahaan. Pada Tabel 9 (halaman 12) dapat dilihat hasil rataan skor pada indikator jaminan mendapatkan nilai sebesar 4,01 yang berarti persepsi pelanggan terhadap jaminan pelayanan publik PLN UPJ Bekasi Kota termasuk kategori baik. Tabel 11 berikut turut menunjukkan bahwa rata-rata reponden memiliki persepsi yang baik terhadap jaminan pelayanan publik PLN UPJ Bekasi Kota. 
Tabel 11 Persepsi pelanggan terhadap kualitas pelayanan publik PLN UPJ Bekasi Kota berdasarkan pernyataan pada indikator jaminan

\begin{tabular}{|c|c|c|c|c|c|c|c|}
\hline \multirow[t]{2}{*}{ Pernyataan } & \multicolumn{5}{|c|}{ Jaminan } & \multirow[t]{2}{*}{ Total } & \multirow{2}{*}{$\begin{array}{c}\text { Rataan } \\
\text { skor }\end{array}$} \\
\hline & 1 & 2 & 3 & 4 & 5 & & \\
\hline Kompetensi dan keterampilan & $\begin{array}{c}0 \\
(0 \%)\end{array}$ & $\begin{array}{c}5 \\
(5 \%)\end{array}$ & $\begin{array}{c}10 \\
(10 \%)\end{array}$ & $\begin{array}{c}70 \\
(70 \%)\end{array}$ & $\begin{array}{c}15 \\
(15 \%)\end{array}$ & $\begin{array}{c}100 \\
(100 \%)\end{array}$ & 3,95 \\
\hline Penguasaan tentang produk & $\begin{array}{c}0 \\
(0 \%)\end{array}$ & $\begin{array}{c}5 \\
(5 \%)\end{array}$ & $\begin{array}{c}11 \\
(11 \%)\end{array}$ & $\begin{array}{c}70 \\
(70 \%)\end{array}$ & $\begin{array}{c}14 \\
(14 \%)\end{array}$ & $\begin{array}{c}100 \\
(100 \%)\end{array}$ & 3,93 \\
\hline Keramahan dan kesopanan & $\begin{array}{c}2 \\
(2 \%)\end{array}$ & $\begin{array}{c}2 \\
(2 \%)\end{array}$ & $\begin{array}{c}5 \\
(5 \%)\end{array}$ & $\begin{array}{c}48 \\
(48 \%)\end{array}$ & $\begin{array}{c}43 \\
(43 \%)\end{array}$ & $\begin{array}{c}100 \\
(100 \%)\end{array}$ & 4,28 \\
\hline $\begin{array}{l}\text { Kepercayaan pelanggan kepada } \\
\text { PLN }\end{array}$ & $\begin{array}{c}2 \\
(2 \%)\end{array}$ & $\begin{array}{c}1 \\
(1 \%)\end{array}$ & $\begin{array}{c}18 \\
(18 \%)\end{array}$ & $\begin{array}{c}65 \\
(65 \%)\end{array}$ & $\begin{array}{c}14 \\
(14 \%)\end{array}$ & $\begin{array}{c}100 \\
(100 \%)\end{array}$ & 3,88 \\
\hline
\end{tabular}

Keterangan: $1=$ sangat tidak baik, $2=$ tidak baik, $3=$ cukup baik, $4=$ baik, $5=$ sangat baik

Tabel 11 menunjukkan bahwa lebih banyak responden yang cenderung menilai baik jaminan yang diberikan PLN UPJ Bekasi Kota dari pada responden yang menilai buruk, terlihat dari rataan skor tiap aspek yang memiliki nilai di atas 3,5. Aspek keramahan dan kesopanan merupakan aspek yang paling diapresiasi oleh responden, terlihat dari aspek ini yang mendapatkan poin lima terbesar dari semua pernyataan yang diajukan yakni sebesar 43 persen.

\subsection{Persepsi tentang Empati (Empathy)}

Empati yaitu kesediaan karyawan dan perusahaan untuk lebih peduli memberikan perhatian secara pribadi kepada pelanggan. Pada Tabel 9 (halaman 12) dapat dilihat hasil rataan skor pada indikator empati mendapatkan nilai sebesar 3,72 yang berarti persepsi pelanggan terhadap empati petugas pada pelayanan publik PLN UPJ Bekasi Kota termasuk kategori baik. Tabel 12 berikut turut memerlihatkan bahwa responden menilai baik terhadap empati karyawan dan perusahaan PLN dalam memberikan pelayanan kepada pelanggan

Tabel 12 Persepsi pelanggan terhadap kualitas pelayanan publik PLN UPJ Bekasi Kota berdasarkan pernyataan pada indikator empati

\begin{tabular}{|c|c|c|c|c|c|c|c|}
\hline \multirow[t]{2}{*}{ Pernyataan } & \multicolumn{5}{|c|}{ Empati } & \multirow[t]{2}{*}{ Total } & \multirow{2}{*}{$\begin{array}{l}\text { Rataan } \\
\text { Skor }\end{array}$} \\
\hline & 1 & 2 & 3 & 4 & 5 & & \\
\hline $\begin{array}{l}\text { Kemudahan menghubungi } \\
\text { Call Center }\end{array}$ & $\begin{array}{c}4 \\
(4 \%)\end{array}$ & $\begin{array}{c}18 \\
(18 \%)\end{array}$ & $\begin{array}{c}40 \\
(40 \%)\end{array}$ & $\begin{array}{c}31 \\
(31 \%)\end{array}$ & $\begin{array}{c}7 \\
(7 \%)\end{array}$ & $\begin{array}{c}100 \\
(100 \%)\end{array}$ & 3,19 \\
\hline $\begin{array}{l}\text { Penuturan petugas jelas dan } \\
\text { mudah dimengerti }\end{array}$ & $\begin{array}{c}0 \\
(0 \%) \\
\end{array}$ & $\begin{array}{c}2 \\
(2 \%)\end{array}$ & $\begin{array}{c}12 \\
(12 \%) \\
\end{array}$ & $\begin{array}{c}54 \\
(54 \%) \\
\end{array}$ & $\begin{array}{c}32 \\
(32 \%) \\
\end{array}$ & $\begin{array}{c}100 \\
(100 \%)\end{array}$ & 4,16 \\
\hline Kesabaran dalam melayani & $\begin{array}{c}1 \\
(1 \%)\end{array}$ & $\begin{array}{c}5 \\
(5 \%)\end{array}$ & $\begin{array}{c}11 \\
(11 \%)\end{array}$ & $\begin{array}{c}70 \\
(70 \%)\end{array}$ & $\begin{array}{c}13 \\
(13 \%)\end{array}$ & $\begin{array}{c}100 \\
(100 \%)\end{array}$ & 3,89 \\
\hline $\begin{array}{l}\text { Perhatian serius petugas } \\
\text { terhadap keluhan }\end{array}$ & $\begin{array}{c}0 \\
(0 \%)\end{array}$ & $\begin{array}{c}6 \\
(6 \%)\end{array}$ & $\begin{array}{c}28 \\
(28 \%)\end{array}$ & $\begin{array}{c}60 \\
(60 \%)\end{array}$ & $\begin{array}{c}6 \\
(6 \%)\end{array}$ & $\begin{array}{c}100 \\
(100 \%)\end{array}$ & 3,66 \\
\hline
\end{tabular}

Keterangan: $1=$ sangat tidak baik, $2=$ tidak baik, $3=$ cukup baik, $4=$ baik, $5=$ sangat baik

Tabel 12 menunjukkan bahwa hampir setiap aspek pernyataan mendapatkan mayoritas nilai empat dari responden. Nilai empat terbanyak terletak pada pernyataan mengenai kesabaran petugas PLN UPJ Bekasi Kota dalam melayani pelanggan, yakni sebesar 70 persen. Aspek kesabaran petugas mendapatkan rataan skor sebesar 3,89 yaitu tergolong kategori baik. Hanya pada aspek kemudahan menghubungi call center dan pelayanan yang mendapatkan mayoritas nilai tiga (cukup), karena para responden menilai nomor telepon yang disediakan sering kali sibuk, dan bahkan ada pula yang mengaku belum pernah menggunakan layanan call center PLN.

\subsection{Persepsi tentang Ketanggapan (Responsiveness)}

Responsiveness atau ketanggapan merupakan kemauan dari karyawan dan perusahaan untuk membantu pelanggan dan memberikan jasa dengan cepat serta mendengar dan mengatasi keluhan yang diajukan konsumen. Pada Tabel 9 (halaman 12) dapat dilihat hasil rataan skor pada indikator ketanggapan mendapatkan nilai sebesar 3,89 yang berarti persepsi pelanggan terhadap ketanggapan pelayanan publik PLN UPJ Bekasi Kota termasuk kategori baik. Tabel 13 berikut turut menunjukkan 
bahwa rata-rata reponden memiliki persepsi yang baik terhadap ketanggapan pelayanan publik PLN UPJ Bekasi Kota.

Tabel 13 Persepsi pelanggan terhadap kualitas pelayanan publik PLN UPJ Bekasi Kota berdasarkan pernyataan pada indikator ketanggapan

\begin{tabular}{|c|c|c|c|c|c|c|c|}
\hline \multirow[t]{2}{*}{ Pernyataan } & \multicolumn{5}{|c|}{ Ketanggapan } & \multirow[t]{2}{*}{ Total } & \multirow{2}{*}{$\begin{array}{c}\text { Rataan } \\
\text { skor }\end{array}$} \\
\hline & 1 & 2 & 3 & 4 & 5 & & \\
\hline Kesediaan membantu & $\begin{array}{c}0 \\
(0 \%)\end{array}$ & $\begin{array}{c}2 \\
(2 \%)\end{array}$ & $\begin{array}{c}5 \\
(5 \%)\end{array}$ & $\begin{array}{c}72 \\
(72 \%)\end{array}$ & $\begin{array}{c}21 \\
(21 \%)\end{array}$ & $\begin{array}{c}100 \\
(100 \%)\end{array}$ & 4,12 \\
\hline $\begin{array}{l}\text { Kesediaan mendengarkan } \\
\text { keluhan }\end{array}$ & $\begin{array}{c}1 \\
(1 \%)\end{array}$ & $\begin{array}{c}0 \\
(0 \%)\end{array}$ & $\begin{array}{c}8 \\
(8 \%)\end{array}$ & $\begin{array}{c}68 \\
(48 \%)\end{array}$ & $\begin{array}{c}23 \\
(23 \%)\end{array}$ & $\begin{array}{c}100 \\
(100 \%)\end{array}$ & 4,12 \\
\hline Pelayanan cepat tanggap & $\begin{array}{c}1 \\
(1 \%)\end{array}$ & $\begin{array}{c}6 \\
(6 \%)\end{array}$ & $\begin{array}{c}18 \\
(18 \%)\end{array}$ & $\begin{array}{c}66 \\
(66 \%)\end{array}$ & $\begin{array}{c}9 \\
(9 \%)\end{array}$ & $\begin{array}{c}100 \\
(100 \%)\end{array}$ & 3,76 \\
\hline $\begin{array}{lll}\begin{array}{l}\text { Respon } \\
\text { tanggap }\end{array} & \text { keluhan } & \text { cepat } \\
\end{array}$ & $\begin{array}{c}2 \\
(2 \%)\end{array}$ & $\begin{array}{c}7 \\
(7 \%)\end{array}$ & $\begin{array}{c}33 \\
(33 \%)\end{array}$ & $\begin{array}{c}47 \\
(47 \%)\end{array}$ & $\begin{array}{c}11 \\
(11 \%)\end{array}$ & $\begin{array}{c}100 \\
(100 \%)\end{array}$ & 3,58 \\
\hline
\end{tabular}

Keterangan: $1=$ sangat tidak baik, $2=$ tidak baik, $3=$ cukup baik, 4= baik, $5=$ sangat baik

Tabel 13 menunjukkan bahwa secara umum responden cenderung menilai baik terhadap pernyataan-pernyataan yang diajukan. Jumlah nilai empat terbesar ialah pada aspek kesediaan petugas dalam membantu pelanggan yakni sebesar 72 persen dan hasil rataan skornya menunjukkan hasil sebesar 4,12 yaitu termasuk kategori baik. Sementara rataan skor terkecil ialah pada aspek kecepatan petugas di dalam merespon keluhan para pelanggan, yakni sebesar 3,58. Pada aspek ini sebanyak 33 persen responden memilih nilai tengah yakni nilai tiga pada aspek kecepatan petugas meresponi keluhan pelanggan dikarenakan ketanggapan petugas dalam menangani keluhan dirasakan oleh beberapa responden tidak konsisten. Terkadang penanganan dilakukan dengan cepat, namun ada kalanya penanganannya lambat. Selain itu, terdapat nilai dua dan nilai satu terbanyak juga di miliki oleh aspek kecepatan petugas dalam merespon keluhan pelanggan. Hal ini juga menunjukkan bahwa kemauan yang baik dari PLN UPJ Bekasi Kota untuk mendengarkan keluhan tidak diikuti dengan respon yang baik pula.

\subsection{Persepsi tentang Wujud Fisik (Tangibles)}

Wujud fisik atau tangibles yaitu berupa penampilan fisik, seperti gedung dan ruangan front office, tersedianya tempat parkir, kebersihan, kerapihan dan kenyamanan ruangan, perlengkapan dan penampilan karyawan. Pada Tabel 9 (halaman 12) dapat dilihat hasil rataan skor pada indikator wujud fisik mendapatkan nilai sebesar 4,06 yang berarti persepsi pelanggan terhadap wujud fisik pelayanan publik PLN UPJ Bekasi Kota termasuk kategori baik. Berdasarkan Tabel 14 dapat disimpulkan bahwa pada setiap pernyataan pada indikator wujud fisik petugas dan juga gedung, mayoritas responden menjawab pada kolom empat yang berarti baik.

Tabel 14 Persepsi pelanggan terhadap kualitas pelayanan publik PLN UPJ Bekasi Kota berdasarkan pernyataan pada indikator wujud fisik

\begin{tabular}{|c|c|c|c|c|c|c|c|}
\hline \multirow[t]{2}{*}{ Pernyataan } & \multicolumn{5}{|c|}{ Nilai } & \multirow[t]{2}{*}{ Total } & \multirow{2}{*}{$\begin{array}{c}\text { Rataan } \\
\text { skor }\end{array}$} \\
\hline & 1 & 2 & 3 & 4 & 5 & & \\
\hline $\begin{array}{l}\text { Penampilan petugas rapih } \\
\text { dan menarik }\end{array}$ & $\begin{array}{c}0 \\
(0 \%)\end{array}$ & $\begin{array}{c}1 \\
(1 \%)\end{array}$ & $\begin{array}{c}6 \\
(6 \%)\end{array}$ & $\begin{array}{c}79 \\
(79 \%)\end{array}$ & $\begin{array}{c}14 \\
(14 \%)\end{array}$ & $\begin{array}{c}100 \\
(100 \%)\end{array}$ & 4,06 \\
\hline $\begin{array}{l}\text { Kebersihan gedung dan } \\
\text { fasilitas lainnya }\end{array}$ & $\begin{array}{c}0 \\
(0 \%)\end{array}$ & $\begin{array}{c}1 \\
(1 \%)\end{array}$ & $\begin{array}{c}6 \\
(6 \%)\end{array}$ & $\begin{array}{c}71 \\
(69 \%)\end{array}$ & $\begin{array}{c}22 \\
(22 \%)\end{array}$ & $\begin{array}{c}100 \\
(100 \%)\end{array}$ & 4,14 \\
\hline $\begin{array}{l}\text { Kenyamanan gedung dan } \\
\text { fasilitas lainnya }\end{array}$ & $\begin{array}{c}0 \\
(0 \%)\end{array}$ & $\begin{array}{c}3 \\
(3 \%)\end{array}$ & $\begin{array}{c}6 \\
(6 \%)\end{array}$ & $\begin{array}{c}69 \\
(69 \%)\end{array}$ & $\begin{array}{c}22 \\
(22 \%)\end{array}$ & $\begin{array}{c}100 \\
(100 \%)\end{array}$ & 4,1 \\
\hline $\begin{array}{l}\text { Perlengkapan yang } \\
\text { gunakan telah memadai }\end{array}$ & $\begin{array}{c}0 \\
(0 \%)\end{array}$ & $\begin{array}{c}1 \\
(1 \%)\end{array}$ & $\begin{array}{c}8 \\
(8 \%)\end{array}$ & $\begin{array}{c}84 \\
(84 \%)\end{array}$ & $\begin{array}{c}7 \\
(7 \%)\end{array}$ & $\begin{array}{c}100 \\
(100 \%)\end{array}$ & 3,97 \\
\hline
\end{tabular}

Keterangan: $1=$ sangat tidak baik, $2=$ tidak baik, $3=$ cukup baik, $4=$ baik, $5=$ sangat baik

Tabel 14 memerlihatkan bahwa responden paling banyak memberikan nilai empat pada aspek memadainya perlengkapan yang digunakan oleh petugas, yakni sebesar 84 persen dan rataan skor yang diperoleh pada aspek ini ialah 3,97 yaitu termasuk kategori baik. Sebesar 79 persen responden 
memberikan nilai empat pada aspek penampilan customer service. Petugas custumer service (loket) dalam bertugas menggunakan seragam rapih, dan berbeda setiap hari dalam seminggu untuk menghindari kesan monoton. Sementara para karyawan lain berpakaian seragam kemeja putih dan abu-abu setiap hari senin dan kamis, batik di hari jum'at, dan di hari lainnya memakai kemeja bebas rapih.

\section{HUBUNGAN ANTARA FAKTOR INTERNAL DAN FAKTOR EKSTERNAL DENGAN PERSEPSI PELANGGAN TERHADAP KUALITAS PELAYANAN PUBLIK PLN UPJ BEKASI KOTA}

\subsection{Hubungan antara Faktor Internal dan Persepsi Pelanggan terhadap Kualitas Pelayanan Publik PLN UPJ Bekasi Kota}

Hubungan antara faktor internal dan persepsi pelanggan terhadap kualitas pelayanan publik PLN UPJ Bekasi Kota diukur menggunakan tabulasi silang dan uji analisis Chi-Square untuk variabel nominal, dan korelasi Rank Spearman untuk variabel ordinal. Hasil pengujian hubungan dapat terlihat pada Tabel 15.

Tabel 15 Hasil pengujian hubungan antara faktor internal pelanggan dan persepsi pelanggan

\begin{tabular}{|c|c|c|c|c|c|c|c|c|c|c|}
\hline \multirow{3}{*}{$\begin{array}{l}\text { Faktor } \\
\text { Internal }\end{array}$} & \multicolumn{10}{|c|}{ Persepsi } \\
\hline & \multicolumn{2}{|c|}{ Kehandalan } & \multicolumn{2}{|c|}{ Jaminan } & \multicolumn{2}{|c|}{ Empati } & \multicolumn{2}{|c|}{ Ketanggapan } & \multicolumn{2}{|c|}{ Wujud Fisik } \\
\hline & Sig & $\begin{array}{l}\text { Cor. } \\
\text { coeff }\end{array}$ & Sig & $\begin{array}{l}\text { Cor. } \\
\text { coeff }\end{array}$ & Sig & $\begin{array}{l}\text { Cor. } \\
\text { coeff }\end{array}$ & Sig & $\begin{array}{l}\text { Cor. } \\
\text { coeff }\end{array}$ & Sig & $\begin{array}{l}\text { Cor. } \\
\text { coeff }\end{array}$ \\
\hline Usia & 0,141 & 0,330 & 0,367 & 0,248 & 0,313 & 0,313 & 0,294 & 0,294 & 0,228 & 0,228 \\
\hline $\begin{array}{l}\text { Tingkat } \\
\text { Pendidikan }\end{array}$ & 0,634 & $-0,048$ & 0,44 & $-0,202^{*}$ & 0,580 & $-0,056$ & 0,016 & $-0,241^{*}$ & 0,031 & $-0,216 *$ \\
\hline $\begin{array}{l}\text { Tingkat } \\
\text { Pendapatan }\end{array}$ & 0,332 & 0,098 & 0,669 & $-0,039$ & 0,993 & 0,001 & 0,424 & $-0,081$ & 0,005 & $-0,281^{* *}$ \\
\hline $\begin{array}{l}\text { Golongan } \\
\text { Daya }\end{array}$ & 0,291 & 0,107 & 0,580 & 0,056 & 0,897 & $-0,013$ & 0,367 & $-0,091$ & 0,128 & $-0,153$ \\
\hline $\begin{array}{l}\text { Frekuensi } \\
\text { Tatap Muka }\end{array}$ & 0,073 & $-0,180$ & 0,569 & $-0,058$ & 0,109 & $-0,161$ & 0,790 & 0,027 & 0,998 & 0,000 \\
\hline $\begin{array}{l}\text { Frekuensi } \\
\text { Menelepon }\end{array}$ & 0,308 & 0,103 & 0,780 & 0,028 & 0,317 & 0,101 & 0,029 & $0,218 *$ & 0,298 & 0,105 \\
\hline Keterangan: & $\begin{array}{l}* \\
* *\end{array}$ & : berhu & & & 0,05 & & & & & \\
\hline
\end{tabular}

\subsubsection{Hubungan antara Usia dan Persepsi Pelanggan}

Uji hubungan ini dilakukan untuk mengetahui apakah golongan usia turut mempengaruhi persepsi sesorang. Hubungan antara usia dengan persepsi diuji dengan menggunakan tabulasi silang dan analisis Chi-Square. Berdasarkan nilai probabilitas (sig) pada persepsi kehandalan (reliability) sebesar 0,141 (Tabel 15) dimana nilainya lebih besar dari 0,05 ( $>>0,05$ ), maka hubungan antara usia dan persepsi kehandalan tidak signifikan atau tidak terdapat hubungan antara usia dengan persepsi terhadap kehandalan. Hasil pengujian usia dengan persepsi mengenai jaminan (assurance) bahwa nilai probabilitas (sig) pada persepsi jaminan sebesar 0,367 (Tabel 15) dimana nilainya lebih besar dari 0,05 ( $>>0,05)$, maka hubungan antara usia dengan persepsi jaminan tidak signifikan atau tidak terdapat hubungan.

Serupa dengan kehandalan dan jaminan, hasil pengujian usia dengan persepsi mengenai empati (empathy) tidak terdapat hubungan atau tidak signifikan. Tabel 15 menunjukkan bahwa nilai probabilitas (sig) pada persepsi empati sebesar 0,094 dimana nilainya lebih besar dari 0,05 ( $>00,05$ ). Uji korelasi antara usia dan persepsi mengenai ketanggapan dalam pelayanan (responsiveness) memiliki nilai probabilitas (sig) pada persepsi ketangapan sebesar 0,150 (Tabel 15) dimana nilainya lebih besar dari 0,05 ( $>00,05)$, maka hubungan antara usia dengan persepsi ketanggapan tidak signifikan atau tidak terdapat hubungan. Dari uji korelasi Chi-Square antara usia dan persepsi mengenai wujud fisik (tangibles) juga diperoleh hubungan yang tidak signifikan atau tidak memiliki hubungan, dengan nilai probabilitas (sig) sebesar 0,481 dimana nilainya lebih besar dari 0,05 
(p>0,05). Dengan demikian, dapat dikatakan bahwa tidak terdapat hubungan antara usia dengan persepsi terhadap kualitas pelayanan publik PLN APJ Bekasi. Karena tidak ada perbedaan bentuk pelayanan kepada pelanggan atau masyarakat berdasarkan usia.

\subsubsection{Hubungan antara Tingkat Pendidikan dan Persepsi Pelanggan}

Uji hubungan ini mencoba untuk mencari tahu apakah tingkat pendidikan seseorang memiliki hubungan dengan persepsinya terhadap kualitas suatu pelayanan publik. Hubungan antara tingkat pendidikan dan persepsi diuji menggunakan tabulasi silang dan analisis Rank Spearman. Tingkat pendidikan diduga memiliki hubungan dengan persepsi pelanggan terhadap kualitas pelayanan publik PLN UPJ Bekasi Kota. Berdasarkan hasil uji korelasi Spearman, hubungan antara tingkat pendidikan dan persepsi terhadap kehandalan (reliability) dan empati (empathy) adalah tidak berhubungan dengan nilai probabilitas (sig) pada persepsi kehandalan sebesar 0,634 dan pada empati 0,580 (Tabel 15) dimana nilainya lebih besar dari 0,05 (p>0,05). Kehandalan dan empati yang diberikan oleh PLN Bekasi Kota cenderung dinilai sama oleh responden dengan pendidikan tinggi atau rendah, yakni dinilai baik. Hal ini karena PLN memberikan pelayanan yang sama untuk semua pelanggan dari segala tingkat pendidikan

Pada Tabel 15 (halaman 14) dapat dilihat hasil uji korelasi antara tingkat pendidikan dengan persepsi terhadap jaminan (assurance) adalah terdapat hubungan yang nyata karena nilai probabilitas (sig) pada persepsi jaminan sebesar 0,044 dimana nilainya lebih kecil dari 0,05 $(\mathrm{p}<0,05)$ dan memiliki koefisien korelasi yaitu -0,202. Tingkat pendidikan dan persepsi terhadap ketanggapan (responsiveness) juga memiliki hubungan yang nyata atau signifikan, terlihat dari hasil uji korelasi dengan nilai probabilitas (sig) sebesar 0,016 dimana nilainya lebih kecil dari 0,05 $(\mathrm{p}<0,05)$ dan memiliki koefisien korelasi yaitu -0,241. Selanjutnya, hubungan antara tingkat pendidikan dan persepsi terhadap wujud fisik (tangibles) adalah nyata atau signifikan karena seperti yang tercantum pada Tabel 15 bahwa nilai probabilitas (sig) pada persepsi terhadap wujud fisik sebesar 0,031 dimana nilainya lebih kecil dari 0,05 $(\mathrm{p}<0,05)$ dan memilki hubungan koefisien korelasi yaitu -0,216.

Jaminan, ketanggapan, dan wujud fisik memiliki hubungan nyata atau signifikan terhadap tingkat pendidikan responden. Ketiganya juga memiliki hubungan yang negatif (koefisien korelasi negatif), yang berarti semakin tinggi tingkat pendidikan seseorang maka persepsinya terhadap jaminan, ketanggapan dan wujud fisik cenderung semakin buruk atau negatif. Hal ini disebakan karena responden yang memiliki pendidikan tinggi lebih kritis dan lebih terbuka dalam mengungkapkan keluhan.

\subsubsection{Hubungan antara Tingkat Pendapatan dan Persepsi Pelanggan}

Hubungan faktor internal tingkat pendapatan dan persepsi pelanggan diuji menggunakan tabulasi silang dan analisis Rank Spearman. Uji ini dilakukan untuk menganalisis apakah tingkat pendapatan yang berbeda mempengaruhi hubungan dengan persepsi pelanggan terhadap kualitas pelayanan publik PLN UPJ Bekasi Kota. Tingkat pendapatan diduga memiliki hubungan dengan persepsi pelanggan terhadap kualitas pelayanan publik PLN UPJ Bekasi Kota.

Dapat dilihat dari hasil uji korelasi pada Tabel 15 (halaman 14) bahwa nilai probabilitas (sig) pada persepsi kehandalan (reliability) adalah sebesar 0,332 dimana nilainya lebih besar dari 0,05 ( $>0,05)$, maka tidak terdapat hubungan antara tingkat pendapatan dan persepsi terhadap kehandalan pelayanan. Selanjutnya, Tabel 15 (halaman 14) juga memperlihatkan bahwa tidak ada hubungan signifikan antara tingkat pendapatan dengan persepsi terhadap jaminan (assurance) karena nilai probabilitasnya sebesar 0,699 dimana nilainya lebih besar dari 0,05 (p>0,05). Tidak terdapat hubungan antara tingkat pendapatan dan persepsi terhadap empati (empathy). Hal ini dapat dilihat berdasarkan nilai probabilitas (sig) pada persepsi terhadap empati sebesar 0,993 dimana nilainya lebih dari 0,05 $(\mathrm{p}>0,05)$, maka tidak signifikan atau tidak terdapat hubungan antara tingkat pendapatan dan persepsi terhadap empati pelayanan. Hubungan antara tingkat pendapatan dan persepsi terhadap ketanggapan 
(responsiveness) adalah tidak signifikan atau tidak terdapat hubungan, oleh karena nilai probabilitasnya (sig) sebesar 0,424. Responden pada tingkatan pendapatan rendah maupun tinggi cenderung memiliki persepsi yang sama, yaitu persepsi yang baik. Selain itu dalam memberikan pelayanannya PLN tidak membeda-bedakan berdasarkan pendapatan seseorang.

Uji hubungan antara tingkat pendapatan dan persepsi wujud fisik (tangibles) memiliki nilai probabilitas (sig) pada persepsi wujud fisik yaitu sebesar 0,005 dimana nilainya lebih kecil dari 0,010 $(\mathrm{p}<0,010)$ sehingga hubungannya sangat nyata atau sangat signifikan, dan memiliki hubungan yang negatif yang dilihat dari koefisien korelasi yaitu sebesar -0,281 yang berarti semakin tinggi tingkat pendapatan responden maka semakin negatif atau buruk persepsinya. Responden yang memiliki pendapatan yang tinggi umumnya sudah biasa dengan fasilitas yg diberikan oleh PLN, seperti misalnya pendingin ruangan (AC) sehingga hal tersebut tidak lagi istimewa.

\subsubsection{Hubungan antara Golongan Daya Listrik dan Persepsi Pelanggan}

Tujuan dari uji hubungan ini adalah untuk mencari tahu apakah golongan daya listrik seseorang memiliki hubungan dengan persepsinya terhadap kualitas pelayanan publik PLN UPJ Bekasi Kota. Hubungan faktor internal tingkat pendapatan dengan persepsi pelanggan diuji dengan menggunakan tabulasi silang dan analisis Rank Spearman.

Pada Tabel 15 (halaman 14) diketahui hasil uji korelasi Spearman antara golongan daya listrik responden dan persepsi terhadap kehandalan (reliability) dengan nilai probabititas (sig) sebesar 0,291 atau lebih besar dari 0,05 ( $>0,05)$ yang berarti tidak ada hubungan diantara golongan daya listrik dengan persepsi kehandalan. Hasil korelasi Spearman antara golongan daya listrik dan persepsi terhadap jaminan (assurance) pelayanan juga menunjukkan tidak adanya hubungan signifikan, dengan nilai probabilitas (sig) 0,580 dimana nilainya lebih besar dari 0,05 (p>0,05). Tabel 15 (halaman 14) memaparkan hasil uji korelasi antara golongan daya listrik dan persepsi terhadap empati (empathy) dengan nilai probabilitas sebesar 0,897 atau lebih besar dari 0,05 ( $>>0,05)$ yang berarti tidak terdapat hubungan antara golongan daya listrik dan persepsi terhadap empati pelayanan.

Berdasarkan Tabel 15 (halaman 14), hasil korelasi Spearman antara variabel golongan daya listrik dan persepsi terhadap ketanggapan (responsiveness) diperoleh hasil 0,367 atau lebih besar dari $0,05(\mathrm{p}>0,05)$ yang berarti tidak terdapat hubungan antara golongan daya listrik dan persepsi terhadap ketanggapan pelayanan. Pengujian terhadap golongan daya listrik dan persepsi mengenai wujud fisik (tangibles) menunjukkan nilai probabilitas (sig) sebesar 0,128 dimana nilainya lebih besar dari 0,05 $(\mathrm{p}>0,05)$, maka hubungan antara golongan daya listrik responden dan persepsi terhadap wujud fisik tidak signifikan atau tidak terdapat hubungan.

Dapat disimpulkan bahwa variabel golongan daya tidak memiliki hubungan dengan persepsi terhadap pelayanan publik PLN UPJ Bekasi Kota. Hal ini karena tidak ada pembedaan pelayanan berdasarkan golongan daya listrik pelanggan oleh PLN. Mulai dari pelanggan dengan golongan daya rendah sampai golongan daya tinggi memiliki hak perlakuan pelayanan yang sama, dan hasil penelitian menunjukkan baik responden yang memiliki golongan daya listrik yang rendah ataupun tinggi didominasi oleh persepsi yang baik terhadap kualitas pelayanan publik PLN UPJ Bekasi Kota.

\subsubsection{Hubungan antara Frekuensi Berhubungan dengan Pelayanan Publik melalui Hubungan Tatap Muka dan Persepsi Pelanggan}

Uji hubungan ini mencari tahu apakah frekuensi berhubungan dengan pelayanan publik melalui tatap muka memiliki hubungan dengan persepsi seseorang terhadap kualitas pelayanan publik PLN UPJ Bekasi Kota. Uji ini menggunakan tabulasi silang dan Rank Spearman. Berdasarkan hasil pengolahan data pada Tabel 15 (halaman 14) antara kehandalan, jaminan, empati, ketanggapan dan wujud fisik, dengan frekuensi tatap muka dengan petugas PLN memiliki nilai probabilitas (sig) masing-masing 0,073; 0,569; 0,109; 0,790 dan 0,998 dimana semua nilainya lebih besar dari 0,05 ( $>0,05)$, maka tidak terdapat hubungan antara frekuensi hubungan tatap muka dengan petugas dan 
persepsi terhadap kehandalan, jaminan, empati, ketanggapan dan wujud fisik pelayanan publik PLN UPJ Bekasi Kota.

Dapat disimpulkan bahwa frekuensi hubungan tatap muka dengan petugas PLN UPJ Bekasi Kota tidak memiliki hubungan dengan persepsi terhadap kualitas pelayanan publik PLN UPJ Bekasi Kota. Hal ini karena dalam enam bulan terakhir tidak diberlakukannya perubahan pelayanan. Dengan demikian, sebanyak apapun pelanggan melakukan hubungan tatap muka dalam enam bulan terakhir relatif tidak berpengaruh kepada persepsi mereka, baik frekuensi rendah ataupun tinggi yang umumnya memiliki persepsi yang cenderung sama yaitu persepsi baik terhadap kualitas pelayanan publik PLN UPJ Bekasi Kota.

\subsubsection{Hubungan antara Frekuensi Berhubungan dengan Pelayanan Publik melalui Hubungan Telepon dan Persepsi Pelanggan}

Uji hubungan ini dilakukan untuk mencari tahu apakah frekuensi berhubungan dengan pelayanan publik melalui telepon memiliki hubungan dengan persepsi seseorang terhadap kualitas pelayanan publik PLN UPJ Bekasi Kota. Frekuensi berhubungan dengan pelayanan publik melalui telepon diduga memiliki hubungan dengan persepsi pelanggan terhadap kualitas pelayanan publik PLN UPJ Bekasi Kota.

Berdasarkan hasil pengolahan data pada Tabel 15 (halaman 14) didapatkan hasil bahwa frekuensi berhubungan dengan pelayanan publik melalui telepon tidak berhubungan nyata dengan persepsi terhadap kehandalan (reliability) pelayanan dengan nilai probabilitas (sig) 0,308 atau lebih besar dari 0,05 ( $>0$,05). Begitu pula dengan uji hubungan antara frekuensi berhubungan dengan pelayanan publik melalui telepon dan persepsi terhadap jaminan (assurance) dan wujud fisik (tangibles) pelayanan, diperoleh nilai probabilitas sebesar 0,780 dan 0,298 atau lebih besar dari 0,05 ( $>0,05$ ), yang berarti tidak terdapat hubungan antara frekuensi pelanggan menelepon petugas dengan persepsi terhadap jaminan pelayanan yang diberikan PLN UPJ Bekasi Kota. Baik responden yang frekuensi meneleponnya tinggi atau pun rendah didominasi oleh persepsi baik terhadap jaminan pelayanan. Dengan demikian, sebanyak apapun pelanggan menelepon petugas pelayanan dalam enam bulan terakhir tidak mempengaruhi pandangan atau persepsinya terhadap kehandalan pelayanan publik yang diberikan PLN UPJ Bekasi Kota.

Hasil uji korelasi pada Tabel 15 (halaman 14) antara frekuensi berhubungan dengan pelayanan publik melalui telepon dan persepsi terhadap empati pelayanan menggunakan uji Spearman, diperoleh hasil sebesar 0,317 dimana lebih besar dari 0,05 ( $>0$,05) yang berarti hubungan adalah tidak signifikan atau tidak terdapat hubungan. Lain halnya dengan uji hubungan antara frekuensi berhubungan dengan pelayanan publik melalui telepon dan persepsi terhadap ketanggapan (responsiveness) pelayanan yang hasilnya menunjukkan bahwa terdapat hubungan yang nyata atau signifikan karena nilai probabilitas lebih kecil dari 0,05 $(\mathrm{p}<0,05)$ yaitu sebesar 0,029 dan memiliki hubungan positif dilihat dari koefisien korelasi sebesar 0,218. Hubungan korelasi yang positif tersebut berarti tingginya frekuensi berhubungan dengan pelayanan melalui telepon diikuti dengan tingginya persepi terhadap ketanggapan pelayanan yang diberikan oleh PLN UPJ Bekasi Kota. Bagi mereka yang memiliki frekuensi menelepon tinggi menilai ketanggapan pelayanan yang diberikan berdasarkan akumulasi pengalaman dari seringnya mereka menelepon.

\subsection{Hubungan antara Faktor External dengan Persepsi Pelanggan terhadap Kualitas Pelayanan Publik PLN UPJ Bekasi Kota}

\subsubsection{Hubungan antara Media Komunikasi dan Persepsi Pelanggan}

Pada faktor eksternal individu terdapat satu variabel yang diuji hubungannya dengan persepsi, yakni media komunikasi. Media komunikasi dalam penelitian ini ialah saluran yang digunakan responden untuk mencari informasi tentang PLN. Uji ini dilakukan untuk menganalisis apakah tingkat penggunaan media komunikasi yang berbeda mempengaruhi hubungan dengan persepsi pelanggan terhadap kualitas pelayanan publik. 
Hasil pengujian korelasi menggunakan Spearman (Tabel 15 halaman 14) nilai probabilitas (sig) pada persepsi kehandalan (reliability) sebesar 0,648 dimana nilainya lebih besar dari 0,05 $(\mathrm{p}>0,05)$, maka tidak terdapat hubungan antara jumlah penggunaan media dan persepsi terhadap kehandalan pelayanan. Media komunikasi juga tidak memiliki hubungan dengan persepsi terhadap jaminan (assurance) pelayanan dengan nilai probabilitas (sig) 0,586 yang lebih besar dari 0,05 $(\mathrm{p}>0,05)$. Berdasarkan hasi pengujian media komunikasi dengan persepsi terhadap empati (empathy) diketahui bahwa nilai probabilitas (sig) sebesar 0,517 dimana nilainya lebih besar dari 0,05 (p>0,05), sehingga tidak terdapat hubungan signifikan antara media komunikasi dan persepsi terhadap empati.

Hasil pengujian korelasi Spearman pada Tabel 15 menunjukkan bahwa antara media komunikasi dan persepsi terhadap ketanggapan adalah tidak signifikan atau tidak terdapat hubungan dimana nilai probabilitas (sig) sebesar 0,243 dimana hasilnya lebih besar dari 0,05 (p>0,05). Serupa dengan empat indikator lain, nilai probabilitas (sig) pada persepsi wujud fisik (tangibles) juga menunjukan nilai lebih besar dari 0,05 ( $>00,05)$ yakni sebesar 0,648 yang berarti hubungan antara jumlah penggunaan media dan persepsi terhadap wujud fisik pelayanan adalah tidak nyata atau tidak signifikan.

\subsection{Kesimpulan}

\section{KESIMPULAN DAN SARAN}

Persepsi pelanggan terhadap kualitas pelayanan publik PLN UPJ Bekasi Kota berdasarkan masing-masing indikator reability (kehandalan), assurance (jaminan), empathy (empati), responsiveness (ketanggapan), dan tangibles (wujud fisik) adalah baik. Secara keseluruhan persepsi pelanggan terhadap kualitas pelayanan publik PLN UPJ Bekasi Kota adalah baik dengan rataan skor sebesar 3,86. Faktor internal responden terdiri dari variabel usia, tingkat pendidikan, tingkat pendapatan, golongan daya listrik pelanggan, dan frekuensi berhubungan dengan pelayanan publik melalui tatap muka maupun telepon. Dari hasil uji hubugan variabel-variabel tersebut dengan indikator service quality (kehandalan, jaminan, empati, ketanggapan, dan wujud fisik) diperoleh lima variabel yang memiliki hubungan nyata atau signifikan, yakni antara tingkat pendidikan dan jaminan, tingkat pendidikan dan ketanggapan, tingkat pendidikan dan wujud fisik, tingkat pendapatan dan wujud fisik, serta frekuensi menelepon dan ketanggapan.

Faktor eksternal terdiri dari satu variebel, yakni media komunikasi. Dari hasil uji hubungan dengan indikator service quality (kehandalan, jaminan, empati, ketanggapan, dan wujud fisik) diketahui bahwa tidak terdapat hubungan antara media komunikasi dengan kehandalan, jaminan, empati, ketanggapan dan wujud fisik pelayanan publik PLN UPJ Bekasi Kota. Dilihat dari hasil uji korelasi antara variabel faktor internal maupun eksternal dengan persepsi pelanggan, dapat dikatakan bahwa faktor tingkat pendidikan merupakan faktor yang paling mempengaruhi pembentukan persepi. Hal ini ditinjau dari hasil uji korelasi tingkat pendidikan dan persepsi yang memiliki tiga hubungan yang nyata atau signifikan dari total lima hubungan yang ada.

\subsection{Saran}

Untuk meningkatkan persepsi pelanggan terhadap pelayanan PLN UPJ Bekasi Kota sekaligus membawa perusahaan kearah citra positif, maka pihak PLN perlu melakukan perbaikan pada beberapa aspek, seperti mengoptimalkan fungsi loket pada unit-unit pelayanan (UPJ), dan memenuhi pelayanan sesuai dengan waktu yang dijanjikan (meminimalisasikan keterlambatan) khususnya untuk pelanggan pasang baru.

Media komunikasi yang paling dianggap efektif ialah komunikasi dua arah yakni melalui petugas PLN baik melalui telepon maupun tatap muka. Oleh karena itu PLN perlu memaksimalkan media tersebut, misalnya dengan menambah saluran telepon untuk pelanggan untuk mengurangi keluhan saluran telepon sibuk. 


\section{DAFTAR PUSTAKA}

Effendy, Onong Uchjana. 1991. Hubungan Masyarakat: Suatu Studi Komunikologis (Revisi). Bandung: Remaja Rosdakarya.

Langgo, Irfan. 2009. Pelayanan Publik PLN dan Realitasnya di Lapangan. http://irfanlanggo.dagdigdug.com/2009/09/06/pelayanan-publik-pln-dan-realitasnya-dilapangan/ diakses pada 29 Maret 2010

Mugnisyah, Siti Sugiah. 2008. Modul Kuliah Pendidikan Orang Dewasa. Bogor.

Rumanti, Maria Assumpta. 2002. Dasar-Dasar Public Relations. Jakarta: Grasindo.

Ruslan, Rosady. 1998. Kiat dan Strategi Kampanye Public Relations. Jakarta: PT. Raja Grafindo Persada.

------------. 2004. Metode Penelitian Public Relations dan Komunikasi. Jakarta: PT. Raja Grafindo Persada.

Sarwono, Sarlito Wirawan. 1999. Psikologi Sosial Individu dan Teori-Teori Psikologi Sosial. Jakarta: Balai Pustaka.

Sinambela, Litjan Poltak. 2008. Reformasi Pelayanan Publik Teori Kebijakan dan Implementasi. Jakarta: Bumi Aksara.

Tjiptono, Fandy. 2006. Manajemen Jasa. Yogyakarta: Andi. 